\title{
A Case of Endobronchial Tuberculosis with Repeated Expectoration of Nodular Tissues
}

Soo Woong Kim, M.D.', Byoung Hoon Lee, M.D.,', Youngsoo Ahn, M.D.,, Nam In Kim, M.D.', Woo Youn Eom, M.D.', Jeong Joo Woo, M.D.', and Sang-Hoon Kim, M.D. ${ }^{1}$

${ }^{1}$ Dept. of Internal Medicine, ${ }^{2}$ Dept. of Radiology, Eulji Hospital, Eulji University School of Medicine, Seoul, Korea

Herein, we report a case of tumorous endobronchial tuberculosis with successful recovery of atelectasis without any significant bronchial stricture, after repeated expectorations of nodular tissues. A 24-year-old male patient was presented with persistent cough. The patient was diagnosed to be suffering from tuberculous lymphadenitis on right axillar and mediastinum of lung, and was subsequently treated with antituberculosis agents. After two months, clinical deteriorations and atelectasis were observed on right upper lobe of lung. Multiple endobronchial tumorous lesions, which obstructed the right main bronchus, were revealed on bronchoscopy, and based on the endobronchial biopsy findings we confirmed that the patient was suffering from endobronchial tuberculosis. We decided to administer antituberculosis agents without any additional procedure. After few weeks, the patient spontaneously expectorated nodular tissues with vigorous coughing. Later on, the symptoms and atelectasis disappeared and the patient was completely recovered. This case shows that in patients suffering from tumorous endobronchial tuberculosis, endobronchial mass can be expectorated spontaneously without sequelae of significant bronchial stenosis. (Tuberc Respir Dis 2005: 59: 204-208)

Key words : Endobronchial tuberculosis, Atelectasis, Bronchoscopy

\section{서 론}

기관지 결핵은 폐결핵 또는 결핵성 림프절염의 중 요한 합병증의 하나로 국내에서 기관지 내시경으로 비교적 빈번히 진단되는 질환 중의 하나이다 ${ }^{1}$. 기관지 결핵 중 일부는 폐암이나 선종과 혼동되기 쉬운 기관 지 내 공간 점유 병변의 형태를 보인다. 이들은 기관 지 내시경 소견에서 종양형으로 분류되는데 단순 흉 부 방사선 검사와 객담 항산균 도말 검사에서 이상 소 견이 없는 경우가 많아서 진단이 쉽지 않달. 이들 종 양형 기관지 결핵은 통상적인 항결핵제와 스테로이드 제 치료에 대한 반응이 느리며, 무기폐 및 이차적인 폐렴 등의 합병증이 흔히 발생하고, 치료에도 불구하 고 대개 기관지의 협착 및 폐쇄가 진행되는 것으로 보

Address for correspondence : Sang-Hoon Kim, M.D. Department of Internal Medicine, Eulji Hospital, Eulji University School of Medicine, Seoul, Korea

Phone : 02-970-8365 Fax : 02-970-8621

E-mail : ksh1134@eulji.or.kr

Received : Apr. 14. 2005

Accepted : Jul. 26. 2005
고되고 있다 ${ }^{2-5}$. 저자들은 기관지 결핵 및 종격동 결핵 성 림프절염 진단 후 항결핵제 치료 중 우상엽에 무기 폐가 진행되면서 증상이 악화되었다가 자발적인 기침 과 함께 기관지내 결절 조직이 여러번 자연 배출된 후 임상 증상 및 검사 소견이 호전된 기관지 결핵 1 예를 경험하였기에 보고하는 바이다.

\section{증 례}

환 자 : 남자, 24 세
주 소 : 기침

병 력 : 20여일 동안 지속되었던 마른 기침을 주소로 2 개월 전 내원하였던 환자로 당시 시행받았던 흉부 방 사선 검사상 우측 폐문부의 침윤이 관찰되어 항생제 치료 후 증상 및 방사선 소견이 호전되었다. 당시 객 담 항산균 도말검사는 음성이었다. 환자는 최근 다시 비슷한 양상의 기침 증상이 발생하여 내원하였다. 객 혈이나 열감은 호소하지 않았다.

과거력 : 폐결핵의 과거력은 없었다.

사회력 : 흡연자로 5 갑년 정도의 흡연력을 가지고 있 
었고 술은 마시지 않았다.

이학적 소견 : 내원 당시 혈압 $120 / 80 \mathrm{mmHg}$, 맥박수 72 회, 호흡수 27 회/분, 체온 $36.9^{\circ} \mathrm{C}$ 였다. 경부 림프절 이나 액와 림프절은 만져지지 않았다. 급성 병색을 띠 었고, 의식은 명료하였으며, 흉부 검사상 국소적인 천 명은 들리지 않았으며, 우측 상부에서 거친음이 청진 되었다. 심잡음은 청진되지 않았고, 체중변화도 없었 으며 그 외 특이사항은 없었다.

검사실 소견 : 말초 혈액 검사에서 백혈구 $4,200 / \mathrm{mm}^{3}$, 혈색소 $13.6 \mathrm{~g} / \mathrm{dL}$, 혈소판 $212,000 / \mathrm{mm}^{3}$ 이었으며, 생 화학 검사상 AST $25 \mathrm{IU} / \mathrm{L}, \mathrm{ALT} 16 \mathrm{IU} / \mathrm{L}, \mathrm{ALP} 198$ IU/L, BUN $11.1 \mathrm{mg} / \mathrm{dL}$, Creatinine $0.9 \mathrm{mg} / \mathrm{dL}, \mathrm{LDH}$ $314 \mathrm{IU} / \mathrm{L}$ 으로 정상이었다. 객담 항산균 도말검사를 세 차례에 걸쳐 시행하였으나 모두 음성이었다.

방사선 검사 소견 : 입원 당시 시행한 단순 흉부 방사 선 사진상 우상엽에 선상의 침윤이 관찰되었다 $(\mathrm{Fig}$ 1-A). 입원 중 실시한 흉부 전산화 단층촬영에서 종격 동과 우측 폐문부의 림프절 비대 소견이 관찰되었다

(Fig 2).

임상 경과 및 치료: 입원 중 우측 액와 림프절이 촉지 되어 림프절 절제 생검을 시행하였고 조직검사상 만 성 육아종성 염증소견이 관찰되었으며 조직에 대한
항산균염색에서 양성소견을 보였다. 액와 및 종격동 의 결핵성 림프절염으로 진단하였고 isoniazid, rifampicin, ethambutol, pyrazinamide 등의 표준약제로 항 결핵요법을 시행하였다. 환자는 치료 시작 후 2 개월 경에 기침과 우측 흉통의 악화를 호소하였고 흥부 방 사선 추적 검사에서 우측 상엽의 허탈이 진행되었다 (Fig 1-B). 당시 시행한 기관지 내시경 검사에서 결절 성 조직이 우측 기관지를 거의 폐쇄시키고 있는 소견 을 관찰하였고(Fig 3), 기관지 내시경하 조직생검에서 육아종성 염증이 관찰되어 기관지 결핵으로 진단하였 다. 다른 추가적인 치료 없이 항결핵제를 지속적으로 사용하면서 인공적인 기침과 위치배농과 같은 물리치 료를 병행하도록 하여 분비물의 배출을 용이하게 하 였다. 우상엽 허탈 발생 이후 2 개월 정도 지났을 때부 터 환자는 기침과 함께 결절조직(Fig 4)을 여러 번 배 출하였고 이후 허탈 소견 및 임상 증상이 호전되었다. 항결핵제 복용 도중 별다른 부작용은 없었으나 간헐 적인 마른 기침이 상당기간 지속되어 항결핵제는 총 14 개월간 투약하고 중단 하였다. 병변의 상태를 확인 하기 위해 기관지 내시경을 재시행 하려 하였으나 환 자가 거부하여 시행하지 못하고 흥부 전산화 단층촬 영만을 시행할 수 있었으며 치료 2개월째 시행하였던
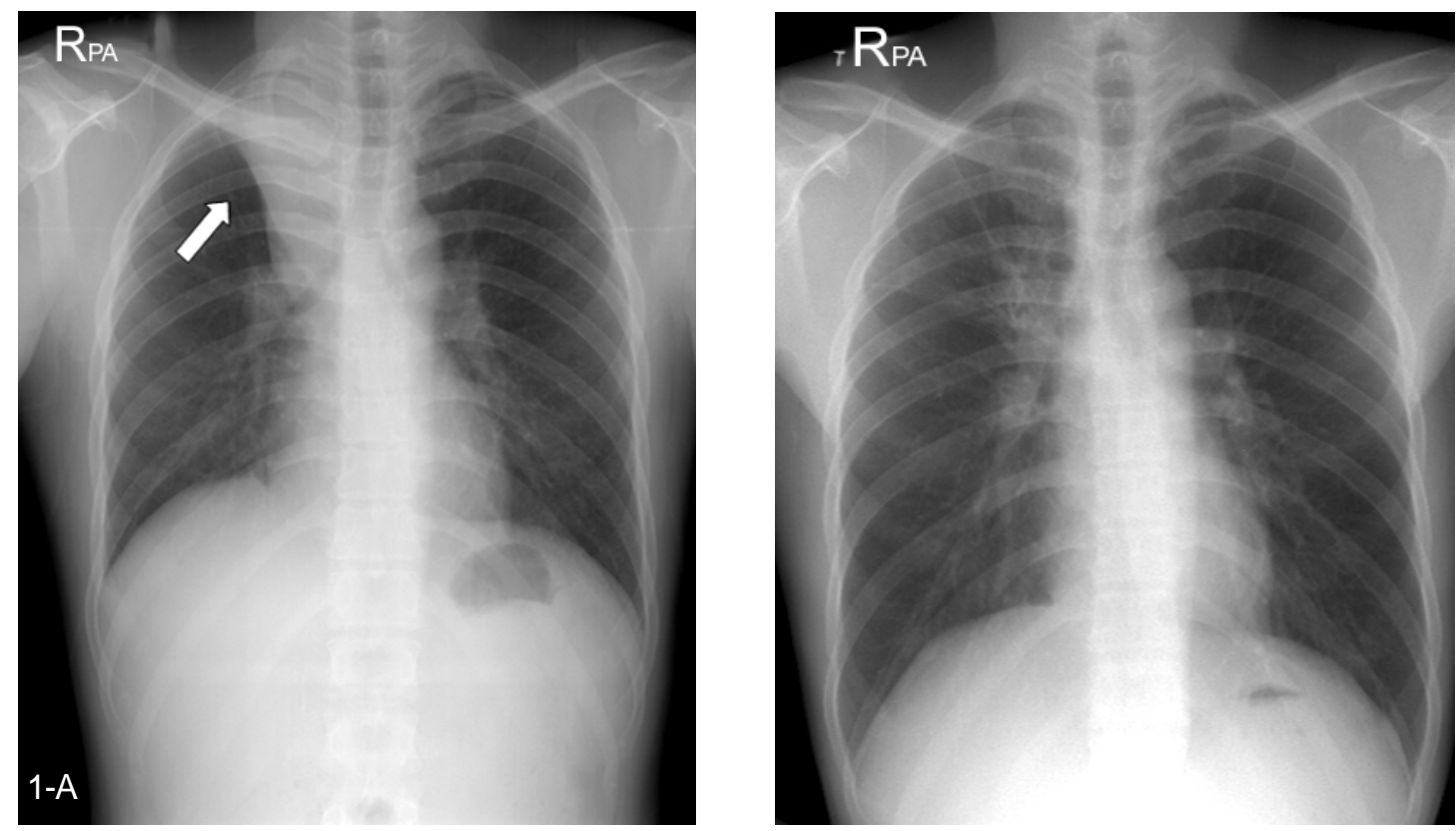

Figure 1. On admission, Chest PA shows linear infiltration in right upper lobe. (1-A) Follow up chest PA shows right upper lobe atelectasis developed during antituberculosis chemotherapy.(1-B) 

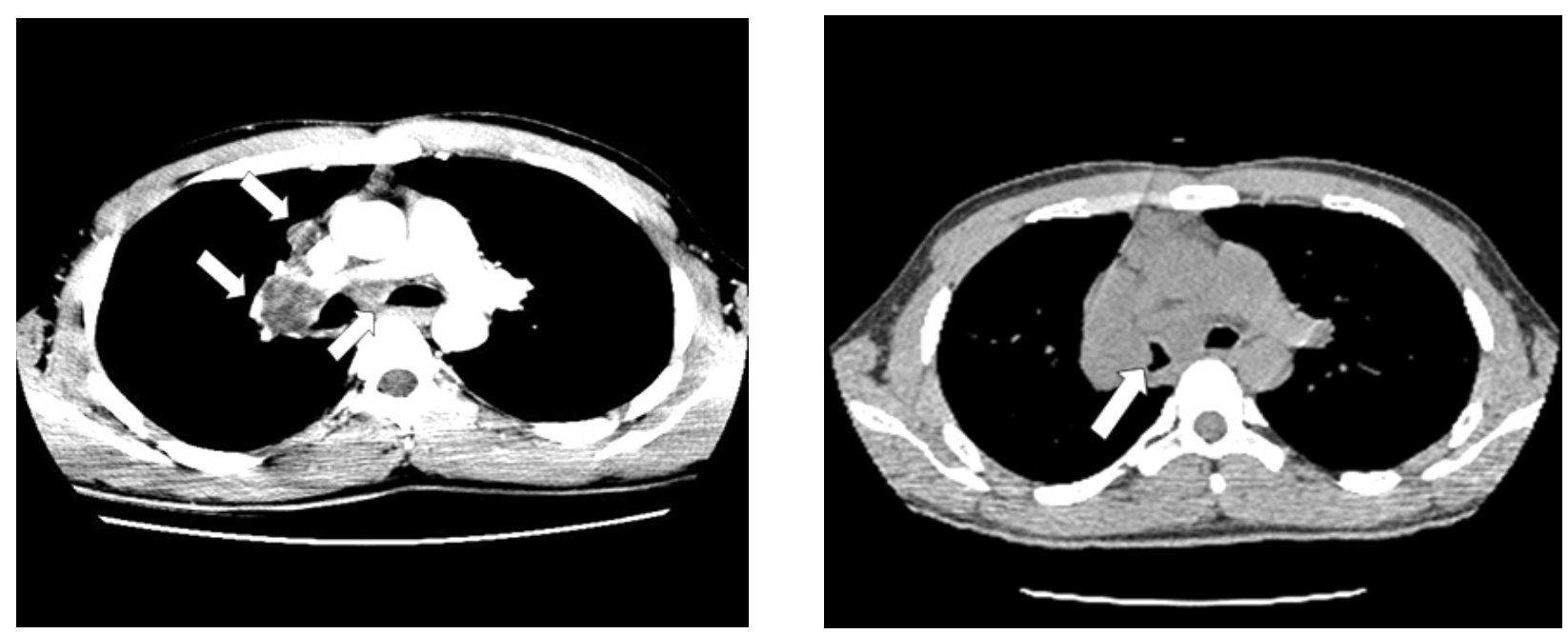

Figure 2. Contrast enhanced computed tomography at the level of the main pulmonary artery bifurcation shows enlargement of right hilar lymph node (arrow) and enlargement of multiple mediastinal node (Nodal station 6,7). After two months, follow up computed tomography (precontrast scan) shows intraluminal protruding mass-like lesion in right upper lobe bronchus.

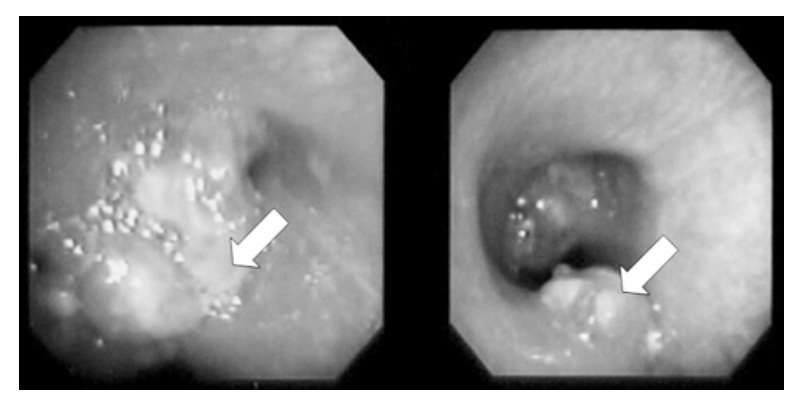

Figure 3. Bronchoscopy reveals multiple nodular tissues obstructing the right main bronchus. Cheese like material was found to cover the nodular tissues (arrow).

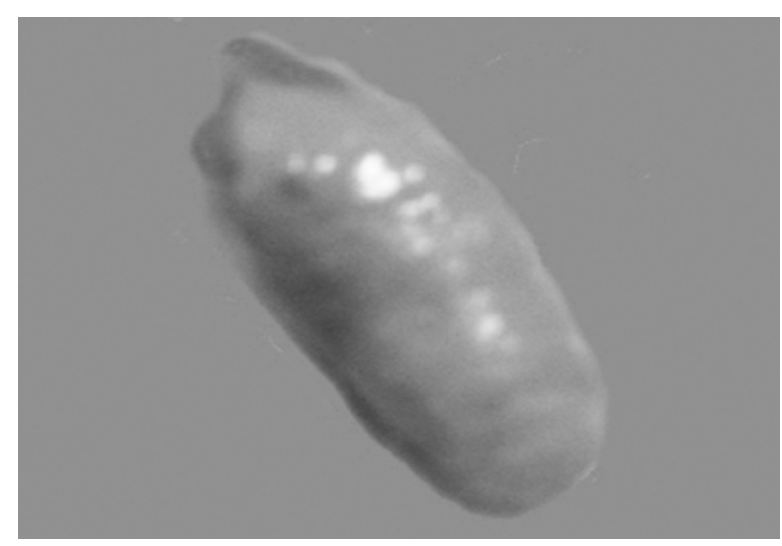

Figure 4. Spontaneously expectorated tissues with vigorous cough.

것과 비교하였을 때 이전에 보이던 기관지내 병변이 없어진 것을 확인할 수 있었다.

\section{고 찰}

기관지 결핵의 기관지 내시경 소견에 따른 분류는 연구자에 따라 다른데, Chung 등 $^{2}$ 에 의한 분류에는 건락성 괴사형(actively caseating), 부종 발적형(edematous-hyperemic), 섬유형 협착형(fibrostenotic), 종 양형(tumorous), 과립형(granular), 궤양형(ulcerative), 그리고 비특이성 기관지염형(nonspecific bronchitic) 의 7가지가 포함된다. 이러한 분류법은 침윤성(infiltrative), 궤양성(ulcerative), 반흔성(cicatricial), 그리고 누공형(fistulous) 혹은 선형(glandular)으로 나눈 6차 폐결핵 학자회의(the Sixth All-Union Congress of Phthisiologists) 분류법 ${ }^{6}$ 이나 국내에서의 안 등에 의 한 점막형, 궤양형, 비후성형, 그리고 협착형으로 나눈 분류법 등 여타의 다른 분류법들과는 서로 공통점이 있으면서도 몇가지 점에서 차이를 보이는데 특히 종 양형을 별도로 언급한 점이 특징적이라 할 수 있다. 치료경과에 따른 기관지 내시경소견의 변화양상을 살 펴본 Chung 등의 연구에 의하면, 치료 후에 비교적 일관된 변화양상을 보였던 여타 형태의 것들과는 달 리 종양형의 경우 변화양상이 복잡하여 예측하기 어 려웠다고 하였으며 이는 종격동 결핵성 림프절염의 침범과 누공 형성에 의한 것으로 추정되는 종양형 기 관지 결핵의 병태생리학적인 독특함에 기인하는 것으 
로 설명하였다.

Chung 등의 분류에 따라 종양형 기관지 결핵으로 분류 할 수 있었던 본 증례는, 종격동 결핵성 림프절 염에 대하여 치료하던 도중에 우상엽이 허탈되면서 기관지 내시경을 시행하여 종양형 기관지 결핵을 발 견하게 되었는데, 이런 경과는 진단 초기에 명백하지 않았던 종격동 결핵성 림프절염의 기관지 침범이 치 료가 진행되면서 누공 등을 형성하게 되고 이로 인한 괴사성 물질의 누출에 의하여 육아종성 염증반응이 유발되어 기관지내 결절을 형성하게된 것으로 추측해 볼 수 있겠다 8.9 . 본 증례에서 처음 종격동 결핵성 림프 절염으로 진단당시 기관지 내시경 검사를 시행하였더 라면 종양형 기관지 결핵으로 진행되기 전단계의 기 관지점막의 변화를 관찰할 수 있었을 것으로 보인다.

이번 증례는 흔히 알려진 종양형 기관지 결핵의 경 과와는 달리 기관지의 협착 내지는 폐쇄가 기관지내 결절 조직의 항결핵 치료에 따른 자발적인 배출에 의 하여 개선되는 경우가 있음을 보여주었다. 기침과 함 께 배출된 결절 조직은 임상 경과 및 배출 전의 기관 지 내시경 소견을 고려할 때 기관지 내의 폐쇄에 관여 하고 있던 육아종으로 생각되고 작은 조각으로 배출 되면서 임상 증상 및 방사선 소견이 호전되었을 것으 로 생각한다. 기관지 내 육아종의 배출 또는 제거가 기관지 협착을 예방하여 장기적인 예후를 호전시킬 수 있는지는 연구가 없어서 분명하지 않으나 기관지 내시경 하에서 가성막을 제거하는 시술이 기도 협착 을 예방하는데 도움이 되고 항결핵제 만으로는 비가 역적인 기관지 협착이 진행하는 경우가 많다는 사실 을 고려하면 보존적인 치료로 호전이 없는 경우 종양 형 기관지 결핵의 치료로서 기관지 내시경하의 제거 시술도 적극적으로 시도해 볼 수 있으나 ${ }^{8}$ 아직 그 근 거는 미약한 실정이다.

종양형 기관지 결핵은 치료에 상당히 저항하여 항 결핵 화학요법을 시행한 후 4-5개월 뒤까지 내시경상 종괴가 남는 경우가 많다고 알려져 있다. 이는 종격 동 결핵성 림프절염과의 관련성이 높기 때문에 치료 기간을 연장하여 1 년 이상 장기치료를 하는 경우가 있 으나 이에 대한 객관적인 증거는 없다. 기관지 결핵의 조기 진단과 빠른 항결핵약제의 투여, 기관지와 림프
절간의 누공에 대한 소작술과 같은 중재적시술이 특 히 종양형 기관지 결핵의 치료에 있어 기관지 협착이 나 폐쇄와 같은 심각한 후유증 발생을 막는데 기여하 는 것으로 알려져 있다. 기관지 결핵의 예후는 섬유 화와 함께 기관지를 완전 폐색하는 경우, 다른 부위에 새롭게 병변이 나타나는 경우, 협착을 유발하는 경우, 저절로 치료되는 경우 등 경과가 다양하여 예측하기 가 어렵다. 따라서 기관지 결핵은 장기간의 세심한 추 적검사를 요하고, 통상적인 항결핵제의 사용에도 불 구하고 병변이 더 진행하거나 협착이 피할 수 없는 것 처럼 보일 경우 결절의 제거를 포함하는 좀더 적극적 인 치료가 필요하다고 생각한다.

기관지 내강의 폐쇄를 치료하기 위해 전신 스테로 이드 요법, 풍선 카테타를 이용한 기관지 확장술 및 팽창성 금속 스텐트 삽입법, 기관지 내시경을 이용한 소파술(curettage), 레이저 요법 등이 현재 시도되고 있고 상황에 따라 폐엽절제술, 기관 및 기관지 성형술 등의 외과적 치료도 추천되고 있다 ${ }^{10-14}$. 기관지 결핵 에서 기도의 협착을 방지하기 위한 전신적인 스테로 이드제의 사용이 흔히 시도되지만 이론적 근거 및 효 과가 아직까지 명백하지 않다 ${ }^{13,14}$. 본 증례에서는 우상 엽의 허탈이 발생한 시점이 항결핵제 복용 후 두 달 경이었으며 특히 스테로이드제에 의한 기관지 협착 방지 효과가 미미한 것으로 예상되는 종양형 기관지 결핵에 해당하여 스테로이드제를 사용하지 않았다.

체위 배농 및 흉부 경타 안마법 등의 물리요법은 보 편적으로 시행되는 시술이지만 이에 대한 연구결과가 적은데 기관지 결핵에 대한 연구에서도 이를 시행했 다는 기록은 있으나 효과에 대하여는 판정하지 않고 있어서 이론적인 근거가 미약하다. 다만 침습적인 방 법이 아니기 때문에 다른 방법보다 우선적으로 시행 해 볼 수 있고 다른 치료와 병행해 볼 수도 있을 것으 로 생각한다.

\section{요 약}

기관지 결핵은 치료 기간이 길고 후유증이 나타날 수 있어 적극적인 치료와 세심한 추적관찰을 요하는 질환이다. 저자들은 항결핵 화학요법 중 무기폐가 진 
행되었다가 특별한 시술 없이 물리치료와 체위배농 만으로 결절 조직이 자연 배출된 후 임상 증상 및 방 사선 소견이 호전된 기관지 결핵 1 예를 경험하였기에 문헌 고찰과 함께 보고하는 바이다.

\section{참 고 문 헌}

1. Park EJ, Kim MO, Yang SC, Sohn JW, Yoon HJ, Shin $\mathrm{DH}$, et al. Clinical and bronchoscopic features of 280 patients with endobronchial tuberculosis (1990-2001). Korean J Med 2003;64:284-92.

2. Chung HS, Lee JH. Bronchoscopic assessment of the evolution of endobronchial tuberculosis. Chest 2000; 117:385-92.

3. Kurasawa T, Kuze F, Kawai M, Amitani R, Murayama T, Tanaka E, et al. Diagnosis and management of endobronchial tuberculosis. Intern Med 1992;31:593-8.

4. Hoheisel G, Chan BK, Chan CH, Chan KS, Teschler H, Costabel U. Endobronchial tuberculosis: diagnostic features and therapeutic outcome. Respir Med 1994; 88:593-7.

5. Smith LS, Schillai RF, Sarlin RF. Endobronchial tuberculosis: serial fiberoptic bronchoscopy and natural history. Chest 1987;91:644-7.

6. Shulutko ML, Kazak TI, Tarasov AS. Chapter9. Tuberculosis. In: Lukomsky GI, editor. Bronchology. 1st ed. St Louis: CV Mosby; 1979. p.287.

7. Ahn CM, Kim HJ, Hwang ES, Kim SK, Lee WY, Kim SJ. A clinical study on 61 cases of tuberculous tr acheobronchitis. Tuberc Respir Dis 1991;38;340-6.

8. Lee JH, Park SS, Lee DH, Shin DH, Yang SC, Yoo BM. Endobronchial tuberculosis: clinical and bronchoscopic features in 121 cases. Chest 1992;102:990-4.

9. Judd AR. Tuberculous tracheobronchitis. J Thoracic Surg 1947;16:512-23.

10. Chung HS, Hyun IG, Han SK. Bronchoscopic electrocautery for airway obstruction in the tumorous type of endobronchial tuberculosis. Tuberc Respir Dis 1991; 38:347-56.

11. Choi YW, Kim YS, Jeon SC, Hahm CK, Choi CS. Treatment of tracheobronchial stenosis with a selfexpandable metallic stents. J Korean Radiol Soc 1994;31:35-41.

12. Caligiuri PA, Banner AS, Jensik RJ. Tuberculous main-stem bronchial stensosis treated with sleeve resection. Arch Intern Med 1984;144:1302-3.

13. Mo EK, Kim HJ, Choi JE, Kim DG, Park MJ, Hyun IG, et al. The effect of corticosteroid on the treatment of endobronchial tuberculosis. Tuberc Respir Dis 1997; 44:409-18.

14. Park IW, Choi BW, Hue SH. Prospective study of corticosteroid as an adjunct in the treatment of endobronchial tuberculosis in adults. Respirology 1997; $2: 275^{-} 81$. 